\title{
Pemberian Pupuk Organik Granular Terhadap Pertumbuhan dan Hasil Kacang Tanah (Arachis hypogea,L) Pada Tanah Ultisol
}

\author{
Markus Sinaga \\ Fakultas Pertanian Universitas Kapuas Sintang. \\ Email: markusagronomi@yahoo.co.id
}

\begin{abstract}
Abstrak: Pemberian pupuk organik granular mampu memperbaiki sifat fisik, kimia, dan biologi tanahpada tanah ultisol,hal ini dikarenakan bahan dasar pembuatannya berasal dari bahan-bahan organik sehingga mampu menambah bahan orgaik tanah. Membaiknya kondisi tanah akan mempengaruhi pertumbuhan tanaman dalam hal ini kacang tanah, sehinggahasil yang diberikan menjadi lebih baik. Penelitian ini bertujuan untuk mengetahui: (1) pemberian pupuk granular terhadap pertumbuhan dan hasil tanaman kacang tanah pada tanah ultisol. (2) Dosis pupuk organik granular yang memberikan pengaruh tertinggi terhadap pertumbuhan dan hasil kacang tanah pada tanah ultisol. Variabel bebas yaitu, pupuk organik granular.Variabel terikat terdiri atas tinggi tanaman, jumlah polong isi, dan berat biji. Penelitian ini menggunakan rancangan acak kelompok (RAK) dengan lima ulangan,perlakuan dalam penelitian ini adalah pemberian pupuk organik granular yang terdiri dari lima taraf perlakuan, yaitu: $\mathrm{p}_{0}=$ tidak diberi organik granular, $\mathrm{p}_{1}=25 \mathrm{~g}$ organik granular per $\mathrm{m}^{2}, \mathrm{p}_{2}=50 \mathrm{~g}$ organik granular per $\mathrm{m}^{2}, \mathrm{p}_{3}=75 \mathrm{~g}$ organik granular per $\mathrm{m}^{2}, \mathrm{p}_{4}=100 \mathrm{~g}$ organik granular per $\mathrm{m}^{2}$. Data dianalisis dengan analisis ragam dan uji Beda Nyata Jujur (BNJ) pada selang kepercayaan 95 dan 99\%. Hasil penelitian diketahui bahwa Pupuk organik granular berpengaruh terhadap hasil tanaman kacang tanah pada tanah ultisol yang ditandai dari jumlah polong isi dan berat polong isi, tetapi tidak berpengaruh terhadap pertumbuhan vegetatif tanaman yang ditandai dengan tinggi tanaman. Dosis organik granular yang menghasilkan jumlah polong isi dan berat biji tanaman kacang tanah pada tanah ultisol adalah 100 gram per $\mathrm{m}^{2}$ tetapi tidak lebih baik dari pemberian 75 gram.
\end{abstract}

Kata Kunci: Pupuk organik granular, pertumbuhan dan hasil, kacang tanah, Ultisol

\section{PENDAHULUAN}

Kacang tanah (Arachis hypogea

L.) merupakan salah satu sumber protein nabati yang cukup peting di Indonesia dalam pola menu makanan di masyarakat, tetapi tigkat produksinya masih sangat rendah, khususnya di Kabupaten SintangProduksi kacang tanah hanya 12,24 kuintal per ha dan ini masih sangat rendah bila dibandingkan dengan potensi optimal yang dapat mencapai diatas 3 ton/ha(Badan Pusat
Statistik Kalimantan Barat,2015).

Puslitbang Tanaman Pangan (2014) merekomendasikan bahwa produksi kacang tanah yang baik dapat mencapai 3,5 ton per hektar.

Rendahnya produksi kacang tanah di Kabupaten Sintang disebabkan oleh beberapa faktor, diantaranya adalah kurang tepatnya pengolahan tanah dan pemberian pupuk. Faktor kecukupan dan keseimbangan hara dalam tanah sangat mempengaruhi tingkat 
pertumbuhan dan produksi tanaman.

Sebagaimana diketahui bahwa sebagian besar masyarakat di Kabupaten Sintang mengembangkan tanaman pertanian dilakukan pada tanah ultisol. Menurut Hardjowigeno (1992), tanah ultisol merupakan tanah dimana terjadi penimbunan liat di horizon bawah, bersifat masam, kejenuhan basa pada kedalaman $180 \mathrm{~cm}$ dari permukaan tanah kurang dari $35 \%$ serta reaksi tanah yang masam, kandungan Al yang tinggi dan unsur haranya rendah, sehingga sangat diperlukan penambahan pupuk guna meningkatkan produksi pertanaman.

Salah satu jenis pupuk yang dapat diberikan pada tanah ultisol adalah pupuk organik granular. Keunggulan pupuk ini dapat memperbaiki struktur dan tata udara tanah sehingga penyerapan unsur hara oleh tanaman melalui akar menjadi lebih baik, dan dapat diaplikasikan pada semua jenis tanah (Petrokimia Gresik, 2014).Pemberian pupuk organik granular pada tanah ultisol mampu memperbaiki sifat fisik, kimia, dan biologi tanah. Hal ini dikarenakan pupuk organik granular mengandung C-organik yang cukup tinggi karena terbuat dari bahan-bahan organik.

Penelitian ini bertujuan untuk mengetahui : (1) pemberian pupuk organik garular terhadap pertumbuhan dan hasil tanaman kacang tanah pada tanah ultisol; (2) dosis pupuk organik granular yang memberikan pengaruh tertinggi terhadap pertumbuhan dan hasil kacang tanah pada tanah ultisol. Ruang lingkup penelitian ini terdiri dari taraf pemberian pupuk organik granular sebagai variabel bebas, dan tinggi tanaman, jumlah polong isi, sertaberat biji sebagai variabel terikat.

\section{METODOLOGI PENELITIAN}

Penelitian ini menggunakan rancangan acak kelompok (RAK) dengan lima ulangan,perlakuan dalam penelitian ini adalah pemberian pupuk organik granular yang terdiri dari lima taraf perlakuan yaitu: kontrol ( $\left.\mathrm{p}_{0}\right), 25 \mathrm{~g}$ organik granular per $\mathrm{m}^{2}\left(\mathrm{p}_{1}\right), 50 \mathrm{~g}$ organik granular per $\mathrm{m}^{2}\left(\mathrm{p}_{2}\right), 75 \mathrm{~g}$ organik granular per $\mathrm{m}^{2}\left(\mathrm{p}_{3}\right)$, dan $100 \mathrm{~g}$ organik granular per $\mathrm{m}^{2}\left(\mathrm{p}_{4}\right)$. 


\section{HASIL DAN PEMBAHASAN}

\section{Hasil}

Hasil pengamatan pemberian pupuk organik granular terhadap peubah yang diamati tertera pada Tabel 1 .

Tabel 1. Rerata hasil pengamatan pemberian pupuk organik granular peubah tinggi tanaman, jumlah polong isi, serta berat biji

\begin{tabular}{cccc}
\hline \multirow{2}{*}{ Perlakuan } & \multicolumn{3}{c}{ Rerata } \\
\cline { 2 - 4 } & Tinggi tanaman $(\mathbf{c m})$ & Jumlah polong isi & Berat biji (g) \\
\hline $\mathrm{p}_{0}$ & 37,80 & 8,00 & 6,65 \\
$\mathrm{p}_{1}$ & 30,55 & 9,50 & 9,20 \\
$\mathrm{p}_{2}$ & 31,45 & 9,90 & 9,90 \\
$\mathrm{p}_{3}$ & 42,85 & 11,25 & 11,75 \\
$\mathrm{p}_{4}$ & 42,85 & 11,50 & 12,15 \\
\hline
\end{tabular}

Sumber: data hasil pengamatan (diolah kembali), 2016

Data dalam Tabel 1 ditampilkan rerata tinggi tanaman tertinggi terlihat pada tanaman $\mathrm{p}_{3}$ dan $\mathrm{p}_{4}$ dengan tinggi rata-rata $42,85 \mathrm{~cm}$, sedangkan tinggi tanaman yang paling rendah pada tanaman $\mathrm{p}_{1}$ dengan tinggi rata-rata $30,55 \mathrm{~cm} . J u m l a h$ polong isi terbanyak pada tanaman $\mathrm{p}_{4}$ dengan jumlah polong isi rata-rata 11,50 polong per tanaman, sedangkan jumlah polong isi terendah pada tanaman $\mathrm{p}_{0}$ dengan jumlah ratarata 8 polong isi per tanaman. Berat biji tertinggi pada tanaman $\mathrm{p}_{4}$ dengan berat rata-rata $12,15 \mathrm{~g}$ per tanaman, sedangkan berat biji terendah pada tanaman $\mathrm{p}_{0}$ dengan berat rata-rata $6,65 \mathrm{~g}$ per tanaman.

Hasil uji $F$ diketahui bahwa pemberian pupuk organik granular tidak berpengaruh nyata terhadap peubah tinggi tanaman, tetapi pengaruh nyata terlihat pada peubah jumlah polong isi, dan berat biji, seperti yang terlihat dalam Tabel 2. 
Tabel 2. Uji F pemberian pupuk organik granular peubah tinggi tanaman, jumlah polong isi, sertaberat biji

\begin{tabular}{|c|c|c|c|c|c|}
\hline \multirow[b]{2}{*}{ SK } & \multicolumn{3}{|c|}{ F hitung } & \multicolumn{2}{|c|}{ F tabel } \\
\hline & $\begin{array}{l}\text { Tinggi tanaman } \\
(\mathrm{cm})\end{array}$ & $\begin{array}{c}\text { jumlah polong } \\
\text { isi }\end{array}$ & berat biji (g) & $\mathbf{0 , 0 5}$ & $\mathbf{0 , 0 1}$ \\
\hline Kelompok & $2,01^{\mathrm{tn}}$ & $1,12^{\text {tn }}$ & $1,25^{\mathrm{tn}}$ & 3,01 & 4,77 \\
\hline Perlakuan & $1,76^{\mathrm{tn}}$ & $5,59^{* *}$ & $16,46^{* *}$ & 3,01 & 4,77 \\
\hline
\end{tabular}

Tabel 3. Uji BNJpemberian pupuk organik granular peubah jumlah polong isi, dan berat biji

\begin{tabular}{ccc}
\hline Perlakuan & JumlahPolong Isi & BeratBiji (g) \\
\hline $\mathrm{p}_{0}$ & $8,00 \mathrm{a}$ & $6,65 \mathrm{a}$ \\
$\mathrm{p}_{1}$ & $9,50 \mathrm{~b}$ & $9,20 \mathrm{~b}$ \\
$\mathrm{p}_{2}$ & $9,90 \mathrm{~b}$ & $9,90 \mathrm{~b}$ \\
$\mathrm{p}_{3}$ & $11,25 \mathrm{c}$ & $11,75 \mathrm{c}$ \\
$\mathrm{p}_{4}$ & $11,50 \mathrm{c}$ & $12,15 \mathrm{c}$ \\
\hline BNJ 0,05 $=$ & $\mathbf{1 , 1 9}$ & $\mathbf{1 , 0 8}$ \\
BNJ 0,01 $=$ & $\mathbf{1 , 4 6}$ & $\mathbf{1 , 3 2}$
\end{tabular}

Keterangan : angka yang ditandai huruf sama menunjukkan tidak beda nyata pada taraf 0,05

Hasil uji BNJ seperti yang terlihat dalam Tabel 3 diketahui bahwa pemberian 100 gram organik granular tidak menghasilkan jumlah polong isi yang lebih banyak dari polong yang dihasilkan oleh tanaman yang diberi 75 gram, selisih antara kedua taraf yaitu 0,25 polong per tanaman. Pada pemberian 50 gram organik granular jumlah polong isi yang dihasilkan tidak lebih banyak dari jumlah polong dari tanaman yang diberi 25 gram organik granular dengan selisih rata-rata 0,40 polong per tanaman. Demikian juga dengan peubah berat biji bahwa pemberian 100 gram organik granular tidak menghasilkan berat biji yang lebih tinggi dari tanaman yang diberi 75 gram. Hal yang sama terlihat dalam berat biji tanaman yang diberi 50 gram organik granular yang juga menghasilkan berat biji yang tidak lebih 
tinggi dari biji tanaman yang diberi 25 gram.

\section{Pembahasan}

Pemberian pupuk organik granular tidak berpengaruh terhadap tinggi tanaman, hal ini diduga karena pertumbuhan vegetatif tanaman kacang tanah tidak terhenti pada saat munculnya bunga, sehingga pertumbuhan tanaman relatif seragam. Selain itu pertumbuhan tinggi tanaman kacang tanah yang tidak nyata antara tanaman yang tidak diberi dan yang diberi pupuk organik granular juga diduga karena unsur hara yang tersedia dalam tanah dalam mendukung pertumbuhan vegetatif tanaman cukup optimal dalam meningkatkan perkembangan sel yang berperan dalam tinggi tanaman terutama unsur nitrogen. Hal ini sejalan dengan pendapat Hardjowigeno (2007) bahwa peningkatan nilai karakter vegetatif seperti tinggi tanaman disebabkan oleh peranan dari unsur nitrogen. Peranan utama nitrogen bagi tanaman adalah untuk merangsang pertumbuhan secara keseluruhan, khususnya batang, dan ketersediaan unsur nitrogen bagi tanaman kacang tanah dapat diperoleh dari pengikatan di udara melalui bintil akar.

Hasil analisa data diketahui bahwa pemberian pupuk organik granular berpengaruh nyata terhadap jumlah polong isi dan berat biji, hal ini diduga bahwa bahan-bahan organik yang terdapat dalam pupuk organik granular dapat terurai dengan baik melalui bantuan mikroba dalam tanah sehingga tersedia bagi tanaman terutama dalam pembentukan polong isi dan pengisian komponen dalam biji kacang tanah. Terurainya bahan-bahan organik yang menjadi bahan dasar dari pupuk organik granular mengakibatkan terbebasnya unsur fosfor dari ikatan koloid tanah, sehingga berpengaruh terhadap jumlah polong isi dan berat biji. Elfarisna dan Pradana (2013) menyatakan bahwa pembentukan polong dan peningkatan kualitas minyak dalam biji kacang tanah salah satunya sangat tergantung pada persediaan unsur hara fosfor dalam jumlah yang banyak.

$$
\text { Hasil uji BNJ membuktikan }
$$
bahwa pemberian 100 gram pupuk organik granular tidak menghasilkan jumlah polong isi dan berat biji yang lebih baik daripada pemberian 75 gram, hal ini diduga bahwa pemberian 75 gram pupuk organik granular per $\mathrm{m}^{2}$ 
sudah mampu memenuhi kebutuhan hara tanaman kacang tanah, sehingga pada pemberian 100 gram tidak meningkatkan jumlah polong isi dan berat biji per tanaman.

$$
\text { Hasil uji BNJ juga }
$$
memperlihatkan bahwa pemberian pupuk organik granular 50 gram tidak menghasilkan jumlah polong dan berat biji yang lebih tinggi dari pemberian 25 gram, hal ini diduga bahwa pupuk organik granular merupakan pupuk yang terbuat dari bahan-bahan organik sehingga unsur-unsur hara yang terdapat di dalamnya relatif rendah yang pada akhirnya akan berpengaruh terhadap kondisi perkembangan dan perbanyakan sel dalam tanaman terutama dalam pembentukan jumlah polong isi dan berat biji. Hal ini sesuai dengan pendapat Lakitan (1995), bahwa proses pengisian polong sangat dipengaruhi oleh jumlah hara yang tersedia di sekitar tanaman. Proses pengisian polong akan berjalan sempurna jika hara $\mathrm{P}$ berada dalam jumlah yang cukup dan tersedia (Dartius 1990).

Pada tanaman yang tidak diberi pupuk organik granular menghasilkan jumlah polong isi dan berat biji yang lebih rendah dibandingkan dengan tanaman yang diberi organik granular.
Hal ini disebabkan karena pembentukan polong isi dan biji tanaman kacang tanah memerlukan unsur hara terutama unsur $\mathrm{P}$, sedangkan tanaman yang tidak diberi pupuk organik granular diduga unsur hara tersebut kurang tersedia bagi tanaman. Selain itu faktor penyebab rendahnya hasil tanaman kacang tanah yang terlihat dari jumlah polong isi dan berat biji pada tanaman kontrol (tanpa organik granular) diduga karena unsur fosfor masih dalam kondisi yang terhambat karena ikatan koloid tanah seperti $\mathrm{Al}$ dan $\mathrm{Fe}$ yang terdapat dalam tanah ultisol.

\section{KESIMPULAN DAN SARAN}

Hasil pengamatan dan analisis data pada penelitian ini diambil kesimpulan sebagai berikut:

1. Pupuk organik granular berpengaruh terhadap hasil tanaman kacang tanah pada tanah ultisol yang ditandai dari jumlah polong isi dan berat polong isi, tetapi tidak berpengaruh terhadap pertumbuhan vegetative tanaman yang ditandai dengan tinggi tanaman.

2. Dosis pupuk organik granular yang menghasilkan jumlah polong isi dan berat biji tanaman kacang tanah pada tanah ultisol adalah 100 gram per $\mathrm{m}^{2}$ 
tetapi tidak lebih baik dari pemberian

75 gram.

\section{DAFTAR PUSTAKA}

Badan Pusat Statistik Kalimantan Barat. 2015. Kalimantan Barat Dalam Angka. Pontianak: Badan Pusat Statistik.

Dartius.1990. Fisiologi Tumbuhan. Fakultas Pertanian Sumatera Utara, Medan.

Elfarisna dan N.T. Pradana.2013. Pengaruh Pupuk Organik Terhadap Pertumbuhan Dan Produksi Tanaman Kacang Tanah. Prosiding Seminar Nasional Matematika, Sains, dan
Teknologi. Volume 4, Tahun 2013, D.48-B.57.

Hardjowigeno, S. 1992. Klasifikasi Tanah dan Pedogenesis. Jakarta: Akademika Pressindo.

Hardjowigeno, S. 2007. Ilmu Tanah. Jakarta: Akademika Pressindo.

Lakitan B. 1995. Dasar-dasar Fisiologi Tumbuhan. Jakarta : Rajawali Pers.

Petrokimia Gresik. 2014. Petroganik. Gresik: Petrokimia Gresik.

Puslitbang Tanaman Pangan. 2014. Budidaya Kacang Tanah Lengkap. Jakarta: Pusat Penelitian dan Pengembangan Tanaman Pangan. Kementerian Pertanian Republik Indonesia. 